\title{
Locating music in capitalism: a view from exile Tibet $^{1}$
}

\author{
A N N A M R COM \\ Music Department, Royal Holloway, University of London, Egham, Surrey, TW20 OEX \\ E-mail: anna.morcom@rhul.ac.uk
}

\begin{abstract}
Since the late 1990s, a thriving scene of pop music has developed among the numerically very small and globally highly dispersed Tibetan exile community. This clearly connects it with globalisation and the spread of what is termed the neoliberal phase of capitalism to India and Nepal where most Tibetan exiles live, and the related spread of digital recording technology and facilities - commodities produced by often large, multinational corporations. Yet this micro industry is not profitable, and even though it is pop music and monetised, it is not 'commercial', and in fact is seen and structured more as 'community work'. Exile Tibetan pop music thus cannot be located outside of capitalism, yet at the same time it is not in and of itself capitalist. In this paper, the author explores new ways in which we can locate music in capitalism, looking beyond the ideas of commercialism or commoditisation and takeover or resistance that have dominated theoretical approaches since Adorno and have fixed popular music especially with a still-enduring 'capitalist' image. The author draws in particular on the historian Fernand Braudel's model of capitalism as an 'anti-market' that lies 'on top' of other social and economic layers. Thus capitalism exerts global hegemony, yet there remain uneven spaces such as exile Tibetan pop music, which are in and of themselves not capitalist, existing within it and because of it.
\end{abstract}

\section{Introduction}

Since the late 1990s, a thriving scene of pop music has developed among the numerically very small and globally highly dispersed Tibetan exile community. This clearly connects it with globalisation and the spread (in various forms and at various levels) of what is termed the neoliberal phase of capitalism to India and Nepal where most Tibetan exiles live, and the related spread of digital recording technology and facilities - commodities produced by often large, multinational corporations. Yet this micro industry is not profitable, and even though it is pop music and monetised, it is not 'commercial', and in fact is seen and structured more as 'community work'. Exile Tibetan pop music thus cannot be located outside capitalism, yet at the same time it is not in and of itself capitalist.

\footnotetext{
1 I would like to extend thanks to the Leverhulme Trust for a Research Fellowship from September 20132014, which has supported the fieldwork and leave to produce this paper. I would like to thank Tim Anderson, Thierry Dodin and Patrick Neveling who all read drafts of this paper and offered invaluable comments. I would also like to thank the two anonymous readers of this paper for their helpful comments and suggestions.
} 
In this paper, I explore new ways in which we can locate music in capitalism through analysis of the micro industry of pop music in exile Tibet. In particular, I look beyond the ideas of commercialism or commoditisation and takeover or resistance that have dominated theoretical approaches since Adorno and have fixed popular music especially with a still-enduring 'capitalist' image. I begin by overviewing the clear trajectories of capitalism's historical advance into musical cultures across the globe, which are intensifying in the present day in many ways but, at the same time, breaking down. I then explore theoretical work on capitalism to seek ways to understand these contradictory currents, and phenomena such as exile Tibet's mass-mediated (albeit on a small scale) pop music that makes no money. I draw in particular on the work of Fernand Braudel, who has been a key theorist and historian of capitalism as a world system, using his model of capitalism as an 'anti-market' that lies 'on top' of other social and economic layers. ${ }^{2}$ Thus capitalism exerts global hegemony, yet remains uneven, enabling spaces such as exile Tibetan pop music, which are in and of themselves not capitalist, to exist within it and because of it. I then turn to the scene of Tibetan exile pop music itself, examining the nature of its connections to global capitalism. Finally, I examine more closely the ways this pop music is valued socially and constructed as community work rather than something to be rewarded with high monetary remuneration, thus delineating this small scene in more detail. Hence I explore not only how exile Tibetan pop music can be located in global capitalism, but its locally produced and idiosyncratic cultural characteristics.

While exile Tibet produces various forms of recorded music, the 'exile Tibetan pop music' I focus on in this paper is that which is produced for a solely Tibetan audience on very low budgets in a pop song format (although some traditional songs also are found in pop albums). This is separate from more 'new age' type Tibetan music catering to a 'world music' market, such as that by Yungchen Lhamo, Ngawang Khechog or Ani Choying Dolma, which has vastly higher production standards, the involvement of big record companies, and does make serious money. The pop music is also distinguishable from recorded albums of 'new age' style Buddhist chanting aimed at a strictly non-Tibetan market of meditation/relaxation music and at foreign Buddhists in the West, and east and southeast Asia, although most of these albums are produced in Kathmandu with the involvement of Tibetan pop singers on budgets similar to those of pop albums. ${ }^{3}$ This music can be significantly profitable and is, ironically, certainly more 'commercial' than the pop music. There are also a handful of exile Tibetan singers who eke out livelihoods in Western countries (often with sponsorship or other support) through performing versions of Tibetan folk music. The most established is Techung, in California. These singers perform for Tibetans as well as broader foreign audiences.

2 The paper does not extend to the more complete world system's approach that would analyze Tibet and exile Tibet within Wallerstein's complex theory of the world interstate system, although it is hoped that this geopolitical approach to capital accumulation and modes of production can be incorporated in future research.

3 Ani Choying Dolma's chanting music is more expensively produced and aimed at the world music market, as well as Buddhists. 


\section{A brief history of music and capitalism to the present day}

A broad economic history of music and capitalism would show clear patterns of change in musical cultures as capitalism has spread across the world from its 15th-century beginnings in Europe to the so-called globalisation of the late 20th century. Large swathes of music in the world have undergone what Polanyi famously described as 'the great transformation' (Polanyi 2001[1944]). Rather than being 'embedded' or 'absorbed' in practices such as religion, ritual, kinship, agrarian production, and in social life in general, by the 21st century, vast amounts of music making are directly involved with commercial interests and, at some level, a profit motive or wage labour. Indirectly, too, corporate funding or even state funding (from revenues generated by taxation) link to the surpluses of capitalist enterprise. Audio and audiovisual technologies of mass production and consumption since the late 19th century have enabled capital accumulation from music on a new scale, and in the early 21st century, at least 75 per cent of (official) global music sales are controlled by the 'majors', a small group of multinational companies. ${ }^{4}$ If we compare this situation with that of the beginnings of capitalism in the 15th century in Europe, or the 19th and early 20th centuries for the globe as a whole, there is a clear change that outlines a penetration of capitalism into musical life. This is the case for live and recorded musics, and for classical, popular and folk musics.

Since the end of socialism and the mass integration of most of the 'developing world' into global capitalism with the spread of (neo)liberal market policies, these processes seem to be intensifying still further. ${ }^{5}$ Recent work brings to light the increasing transformation of bands into brands (Paoletta 2005; Carah 2010; Anderson 2014, p. 167); even independent popular music in Western countries, rather than being oppositional, has been shown to serve the interests of big corporations via advertising and sponsorship (Carah 2010; Taylor 2012; Eckhardt and Bradshaw 2014). Since the latter decades of the 20th century, vastly more folk music has become mediatised and intertwined with popular music, market exchange and tourism. ${ }^{6}$ Corporate sponsorship has burgeoned in both Western and Indian classical music. Both classical and popular musics have, in addition, found new repackaged and recreated forms for individual, independent, indoor listening rather than collective performances and listening in concert halls, cinemas or outdoors in public bazaars.7 Other clear links between music and capitalism in the neoliberal world can be seen in the increasing use of music in initiatives targeted to solve social and health problems, build skillsets and so on. Thus music is increasingly used instrumentally for purposes

\footnotetext{
${ }^{4}$ See Azenha (2006, paras 62-63) for a fairly recent analysis of the figures.

${ }^{5}$ The degree of disruption of socialism to the history of music and capitalism is complex and beyond the scope of this paper. However, it can be stated that socialism is not in all ways an opposite of capitalism, being industrial, subsumed with ideologies of progress, and also encompassing growth and accumulation, although by the state rather than by private individuals. It is for these reasons that many socialist performing arts have transitioned easily into market economies. I explore these matters of socialist and capitalist synergy elsewhere, looking at the state style of Tibetan folklorised music in the global, market era (Morcom 2007). Wallerstein (2014) analyses socialism as ultimately not anti-systemic to the capitalist world system.

${ }^{6}$ The transformation of much 'folk' music into vernacular pop genres was greatly expanded with cassette technology, as Manuel's (1993) ground-breaking study of India illustrates. On tourism see Hellier-Tinoco (2011), Hughes-Freeland (2012) and Scarangella-McNenly (2012).

${ }^{7}$ Krims (2001) has discussed this with respect to the repackaging of classical music for new urban environments.
} 
of (social) productivity, and in the process justified, rather than being valued through more generalised notions of entertainment. ${ }^{8}$ Performers can also be seen to be increasingly framing themselves and being framed in discourses of entrepreneurship as they develop careers in post-Fordist flexible capitalism. ${ }^{9}$ In addition, copyright regimes have been instituted in more and more of the world. ${ }^{10}$

However, although there are clear trajectories of change as we view the history of music and capitalism up to the neoliberal, and now digital and Internet era, at the same time it is well known that music industries are in the midst of a profound crisis brought on by the huge loss in profitability due to piracy and freeloading that has arisen from digital technology. Even the mainstream of English language pop music - the epitome of 'commercial music' - is unsure about its future. Beyond this mainstream, many music industries are in fact no longer being run for profit, or are relying on patronage, and discourses of pop music as gift exchange and social participation are gathering pace (Baym 2011; Anderson 2014). In terms of music and copyright, Frith and Marshall (2004, pp. 209-13) identify the music industry(ies) as a whole as being pulled in two directions - copyright totalitarianism and copyright anarchy.

This brief synopsis of music and capitalism up to and in the present moment gives a sense of, on the one hand, the deepening hold of capital's tentacles on music, and on the other, their weakening or collapse. Indeed, the image or impression of capitalism is often that of a wall that advances and may be fought back, or that may collapse in crisis - a binary, an either/or. Adorno's foundational work on music and capitalism outlined very much a takeover of music by capitalism, and paradigmatically defined pop music as synonymous with capitalism; pop music was the ultimate commodity, churned out in standardised form by Fordist corporate mass production, leaving its listeners passive and 'hemmed in by standardized goods', victims of commodity fetishism (Adorno 1978[1938]). This perspective has been critiqued, in particular by scholars of popular music, with a rejection of the notion that listeners were duped and alienated. Instead, scholars have explored how popular music, although bought and sold and a part of commodity chains, is nevertheless used actively, creatively and with authentic pleasure and experience. However, the current crisis of the music industries and the collapse of the archetype of pop music as commodified music has demanded new ways of looking at music and capitalism. Work has begun to emerge in recent years which addresses music, commodification, markets and monetisation in ways that are more flexible and contextual than Adorno, and also less ideological (Stokes 2002; Laing 2003; Taylor 2007). This research embraces a far more complex picture of capitalism, not grounded in technological determinism. My approach aims to continue this trajectory, but through drawing from a different body of theory.

\section{The uneven, unstable and unpredictable fabric of the capitalist world system}

Scholars of the tradition of liberal economics understand capitalism as not total or entire, for example, acknowledging the existence of 'externalities' as a part of market

\footnotetext{
8 See Whittaker (2014); Morcom (2015).

9 See Anderson's (2014) study of pop musicians in the post-digital world; Butterworth (2014) discusses Andean divas; Morcom (2013, pp. 117-40) looks at Bollywood dancers.

${ }^{10}$ Rees (2003) describes this process in China, and its implications.
} 
exchange, and markets as never completely encompassing social and economic life. ${ }^{11}$ Marxist scholars, although disagreeing drastically as regards the social consequences of market exchange or 'capitalism', also do not see it as complete. Straightforwardly, David Harvey defines capitalism as 'any social formation in which processes of capital circulation and accumulation are hegemonic and dominant in providing and shaping the material, social and intellectual bases for life' (Harvey 2014, p. 7). Thus, being hegemonic, capitalism exerts some kind of an overarching power. However, capital's power is not total, and there is a distinction between 'capital' and 'capitalism' (Harvey 2014, pp. 7-11). Polanyi sees the entire takeover by capital in a society as impossible, with 'the great transformation' never complete; thus society can never be 'commodities all the way down' (Fraser 2012). Rather, Polanyi's theory sees the disembedding of economy from social life through the creation of the fictitious commodities (land, labour and money) as always limited, eventually triggering the 'double movement', where society fights back (Polanyi 2001 [1944]). Using a simpler image, Holloway's (2010) polemical book Crack Capitalism describes capitalism as intrinsically riddled with cracks which may expand - or be actively expanded - to bring about change or, indeed, may close up, strengthening capitalism's fabric in a given place or time.

Braudel's work differs from these approaches in understanding spaces that are not in and of themselves capitalist specifically as an inherent and integral part of a capitalist world system - indeed, as essential to its workings. Braudel was a formative scholar of the world systems approach, developed subsequently by Immanuel Wallerstein, Giovanni Arrighi, and others. The world systems school sees capitalism as an all-pervasive, transformational and towering global hegemonic force that has advanced across space and time since its beginnings in Renaissance Italy. But, crucially, this advance is not linear, stable or even. Rather, as Neveling (2013) states, capitalism is a 'much more contradictory and patchwork-like sociohistorical phenomenon' than typically envisaged. ${ }^{12}$ Fernand Braudel, in his work on the history of Europe and capitalism from the 15th to 18th centuries, theorises capitalism as existing in layers:

... the lowest stratum [is that] of the non-economy, the soil into which capitalism thrusts its roots but which it can never really penetrate. ... Above it, comes the favoured terrain of the market economy, with its many horizontal communications between the different markets: here a degree of automatic coordination usually links supply, demand and prices. Then alongside, or rather above this layer, comes the zone of the anti-market, where the great predators roam and the law of the jungle operates. This - today as in the past, before and after the industrial revolution - is the real home of capitalism. (Braudel 1982, pp. 229-30)13

11 The term 'capitalism' has in fact been little used by (mainstream) economists, and is more characteristic of Marxist approaches that focus on questions of power and inequality.

12 For a more comprehensive exploration of this approach in a published article, see Neveling (2014).

13 Quoted also in Arrighi (2009[1994]), pp. 10-11. It is important to note that the world system view of capitalism, while drawing much from Marxism, also differs from both it and the liberal tradition in seeing capitalism as not located in markets but in the anti-market, an arena of monopoly, of unequal competition. This also distinguishes Braudel's work from Polanyi's. Braudel is highly critical of Polanyi's notion of the disembedding of economies from social life and a distinguishing of social from economic exchange, focusing rather on the location of the anti-market (Braudel 1982). See also Barber's article critiquing Polanyi's concept of the possibility of an economy (dis)embedded from social life, but also citing 'embeddedness' as not a pivotal theory of The Great Transformation (Barber 1995). 
While Braudel's research focuses on life prior to 1800, as Harvey points out, in today's world there is no longer a layer into which capitalism has not thrust its roots and penetrated, and crises of capitalism such as we saw in 2008 wreak devastation on lives everywhere. For these reasons, Harvey sees Braudel's model as no longer relevant (Harvey 2006, pp. 78-9). However, this model can be adjusted to the present day to see capitalism as an all-pervasive (if not always visible or conscious) presence, something that is linked to and transformational of all parts of life in some manner, an overall hegemony of capital but, at the same time, as containing spaces or lower or middle layers which do not in and of themselves produce the levels of accumulation that exert hegemonic power in a world system, but are essential to the predatory anti-market.

Furthermore, as Marxist and also non-Marxist scholars have shown, capitalism is not stable but inherently prone to crisis; in fact, it requires crises and destruction for its survival and spread, encapsulated in the phrase made famous by Schumpeter (1975[1942]), 'creative destruction'. Thus, along with its advance come disruptions and seismic shifts, closely relating to technology, and hence changes in the location of layers, or of cracks versus smooth fabric. ${ }^{14}$

Such a world systemic view of capitalism as layered but unstable or non-linear enables us to connect the 'patchwork-like' disparate and apparently contradictory trends and aspects of music making. In the phenomena of loss-making (pop) music in today's world, we see elisions, unevenness, layers, or (to use Holloway's term) cracks that exist very much within and also because of a larger capitalist fabric, rather than being necessarily exceptions or resistance to capitalism. This is an important nuance. Capitalism is certainly powerfully hegemonic and all-pervasive; but, ontologically, it is not solid, total or stable. Rather, crises must exist, as well as layers where surplus is not retained and accumulation does not take place.

At the time Adorno was writing, the advance of capitalism would have seemed to predicate more and more music being taken over by (corporate) capitalism and being driven by profit motive and commercialism; pop music's mass production in object-commodity form was a new watershed in the extraction of surplus value from music. However, with the more recent crisis of profitability in large amounts of pop music, the trajectory is clearly far more complex. Technology is core to capitalism's advance yet also a linchpin of its instability, and thus must be placed in a nondeterministic position vis-à-vis the topography of accumulation across time and space. In relation to music, the location of the anti-market versus the lower layers has seen a large shift in recent decades.

It is also crucial to note that just because a phenomenon is monetised or marketised does not mean it is an example of the upper layer of the capitalist system; it may just as much be within the lower or middle layers. Monetisation and marketisation do not equal, in and of themselves, a capitalist political economy, as the case of the exile Tibetan pop industry will illustrate. In fact, money and markets long predate capitalism, and Braudel sees the layer of market exchange as not 'the real home of capitalism'. ${ }^{15}$ However, the spread and expansion of money and market exchange

14 The unstable relationship of technology, labour and capital is outlined in Volume I of Capital in Chapter 15, 'Machinery and large-scale industry' (Marx 1990[1867]). For a contemporary analysis of this, see Harvey's Limits to Capital (2006[1982], pp. 98-136 in particular).

15 See Polanyi et al. (1957) on long histories of money and trade before capitalism. 
have underpinned the spread and expansion of capitalism. ${ }^{16}$ Taylor has elucidated these important points with respect to music in his article on the music commodity. Drawing from Marx, he states that the sale of music (recorded or live) for money does not necessarily make it a 'commodity'. Rather, it is only if it 'enters the system of capitalist exchange, where it can be used to generate surplus value' that it is a commodity; otherwise, its sale may make it only a product (Taylor 2007, p. 282). In today's world, due to the spread of capitalism, most music is incorporated into monetised and indeed mediatised economies, and exchanged to some degree via markets. However, this does not necessarily make it a (direct) medium of capital accumulation, a space that is in and of itself capitalist. Indeed, capitalism does not lie in isolated spaces, but only exists as a larger system.

\section{The (micro) pop music industry of exile Tibet}

I now turn to the world of exile Tibet to explore ways, using this methodology, in which we can locate music in capitalism in terms of connections to the 'anti-market', the verticalities of accumulation that sustain the world system. This involves an exploration of the costs and technology of pop music production, the hype of pop concerts, the music livelihoods this scene overwhelmingly does not sustain, and the global commodity chains it relies on. I then look more closely at the logics of exchange and the value of music in exile Tibet. This information is drawn from fieldwork conducted in Kathmandu in October 2013 and July 2014, in Minneapolis and New York in November 2013, and in Dharamsala in March 2014, including interviews with numerous Tibetan exile singers. The paper also rests on 25 years of involvement with exile Tibetan society and many years of active participation in musical culture. It is additionally supported by fieldwork in Tibet itself between 2004 and 2007, which included making a VCD album of Tibetan songs with a co-singer there, which was also copied and distributed in India and further afield by myself.

Prior to the transformations of the modern world which affected Tibet largely in the mid- but also earlier 20th century, Tibetan (non-monastic) folk songs and dances were largely the preserve of non-professionals, based in the largely subsistence agrarian life of Tibetan nomads and farmers, although some styles existed that were performed by professionals or semi-professionals in structures of patronage. ${ }^{17}$ Very limited connections to more cosmopolitan modern life existed in Lhasa by the first part of the 20th century, together with isolated drives to modernise culture. Although trade and political alliances had linked Tibet to the wider world from before the 20th century, and there were modern-thinking intellectuals (including communists) in the early 20th century who criticised Tibet's traditional and theocratic foundations, the sweeping transformations to Tibet and Tibetan musical culture came after 1950 and 1951 when China annexed extensive Tibetan indigenous areas to its west. ${ }^{18}$ A new modern, socialist form of Tibetan performing arts was created, led by

16 Harvey (2014, pp. 25-37) summarises the role of money in capitalist expansion.

17 See articles on 'Traditional music; folk music' by Isabelle Henrion-Dourcy, Tsering Dhondhup and Mark Trewin in Pegg et al. (2001). For a superb contemporary ethnography of folk music in rural Tibet with photographic illustrations, see Zla ba Sgrol ma (2012).

18 This is not limited to the Tibet Autonomous Region, the province that in China is referred to as 'Tibet', and also includes parts of Qinghai, Gansu, Sichuan and Yunnan. For clarity, I refer to these Tibetan 
specialist performers, composers and other cultural cadres and incorporated into the national system of song and dance troupes (Morcom 2004, pp. 13-52). After the end of the Cultural Revolution in 1976, as China started to move towards a market economy, non-state, private spheres of music making gradually emerged, including popular music from the late 1980s (Morcom 2004, 2008; Henrion-Dourcy 2005). ${ }^{19}$

The Chinese annexation of Tibet led, in 1959, to an immense uprising in Lhasa, and the Dalai Lama fled to India, followed by 80,000 Tibetans. ${ }^{20}$ This was the birth of exile Tibet. A government in exile was established in Dharamsala in north India in 1960 and Tibetans have continued to come out of Tibet since this time. The vast majority of exile Tibetans live in south Asia, in India $(94,203)$, Nepal $(13,514)$ and Bhutan (1,298). ${ }^{21}$ However, communities have formed in Western countries too, in particular from the late 1990s. Thus the Central Tibetan Administration (formerly the Government in Exile) lists a population of 18,999 in countries beyond south Asia.

Exile Tibet can be seen convincingly as a nation state, although of course not one with territory (McConnell 2009). An important part of the creation of this exile-statehood has been the Tibetan Institute of Performing Arts (TIPA), set up in 1959 and funded by the Tibetan government in exile and private donors (Diehl 2002, pp. 68-72). TIPA has succeeded in preserving non-sinicised versions of Tibetan performing arts, albeit in (inevitably) reinvented, folklorised, 'national' forms, for example, with professionals performing music and dance traditionally performed by nomads and farmers. ${ }^{22}$ TIPA is thus consonant with the transformation of performing arts by nationalism (socialist and liberal-democratic) across the world (Morcom 2011). TIPA has remained an important core of exile musical Tibetan culture, providing music teachers for Tibetan schools across India and Nepal, and with many ex-TIPA artistes now voluntarily teaching music and dance in Tibetan communities outside south Asia. Within Tibetan settlements, traditional forms of folk music have continued, although less and less as time has passed.

Tibetan exile modern songs can be traced to around 1970 (Diehl 2002, pp. 1789). However, recorded/album-based music, with the stylistic characteristics of popular music (more specifically, rock or folk rock) is more recent, dating from 1988 with the group Rangzen Shonu (Freedom Youth) in Dharamsala, whose songs became an iconic part of exile Tibetan life (Diehl 2002, pp. 175-206). Soon after, TIPA also launched its own rock band, Akama, a nod of compromise from TIPA's strict preservationism (Diehl 2002, pp. 183-4). Other bands and singers also emerged and recorded albums in the 1990s, such as the Yak Band ${ }^{23}$; Phurbu T Namgyal, one of the biggest stars now, released his first album in 1995, although it was only distributed in Tibetan settlements in south India.

Tibetan exile pop music reached a new stage in 1996-1997 with the release on cassette of Tsering Gyurme's Tsawai Lama ('Root Lama', the Dalai Lama in this case).

areas of China collectively as 'Tibet'. Tibetan cultural areas also extend beyond China's borders, and as a whole are often referred to as 'Greater Tibet'.

19 See also Baranovitch (2003) on popular music and the Chinese state.

20 This is the figure given by McConnell (2009, p. 343).

21 Statistics from the Central Tibetan Administration, Dharamsala. http://tibet.net/about-cta/tibet-in-exile/ (accessed 18 April 2014).

22 For further discussion of TIPA, see Diehl (2002) and in the perspective of nationalism, Morcom (2011, pp. 386-94).

23 See Diehl's (2002, pp. 175-206) overall discussion of the emergence of Tibetan exile modern/rock music. 
Tsawai Lama sold 500 copies, and created an immense craze across exile society with its peppy, synth-based pop style as opposed to previous rock and folk-rock music. ${ }^{24}$ Like a number of exile pop musicians, Tsering Gyurme had studied at TIPA - in his case, spending four years there, including time following the teacher-training programme and playing in Akama. He returned to Kathmandu in 1996 to teach Tibetan music at a primary school. His training at TIPA was crucial to his ability to play Tibetan music and instruments (dranyen - lute, piwang - vertical fiddle, and yangchen - dulcimer) and to weave these into Tibetan pop songs. Tsering Gyurme also created pop versions of traditional songs, something he was criticised for by some, especially initially, but that has continued and is also extremely widespread in Tibet. In addition, he established Kathmandu as the centre of exile Tibetan pop music production. By 2000, Tsering Gyurme had made several albums (Figure 1), and was largely responsible for the vanguard of exile pop music. From around 2000 many more new singers started to emerge or gain visibility. CDs also started to supersede cassettes. Exile pop thus expanded dramatically in the 2000s, with some 20 albums released in a given year (Figure 2). New singers have continued to emerge up to the present day.

\section{Album production and distribution}

Being a teacher at a primary school in Kathmandu hardly gave Tsering Gyurme the means to fund an album, so he borrowed money from friends who encouraged him. Making the master for Tsawai Lama cost a total of US\$320 (Nepali Rupees [Rs] 18,000 ), and US $\$ 0.21$ (Rs 11/12) to print each cassette. ${ }^{25}$ Thus he made 500 cassettes and spent a total of US $\$ 420$ (Rs 23,500). Selling all the 500 cassettes at the standard price of the time of Rs 72, he eventually would have received up to US\$643 (Rs $36,000)$, enough to cover the costs of production, but given the amount of time involved in the process, not enough to live off, let alone make a profit. ${ }^{26}$

During this period, various more or less formal systems for distribution developed, with several shops in Kathmandu, and music sold in Dharamsala, the Tibetan area of Delhi (Majnu Ka Tilla), and settlements in south India. Distribution also reached Tibet, with businessmen taking small numbers of non-political albums for sale there, where pirate copies were made and sold. The singers made no money from this. The formal distributors had some limited means to sell albums in the West, but people also sent albums to friends settled there, who sold them. Availability of Tibetan music increased vastly in the 2000s compared to the early and mid-1990s. Singers also got the opportunity to sell albums at the big Tibetan New Year concerts that began in south India in 2003-2004 and, from 2005, in North America.

It was possible to break even on album costs in the mid-2000s. However, sales became harder with the combination of cassette/CD piracy and free sharing via the Internet in the latter part of the 2000s, and more and more people exchanged

24 The song can be listened on YouTube, with the video obviously recently constructed. https://www.youtube.com/watch?v=O8v6lfbNjTE (accessed 14 June 2014).

25 At that time US\$1 was approximately equivalent to Rs 56; at the time of my fieldwork in 2013-2014, it was approximately Rs 100.

26 See Diehl for a description of the Yak Band's making and selling an album in 1995 which, although successful, made a loss after all expenses were factored in (Diehl 2002, pp. 201-2). 


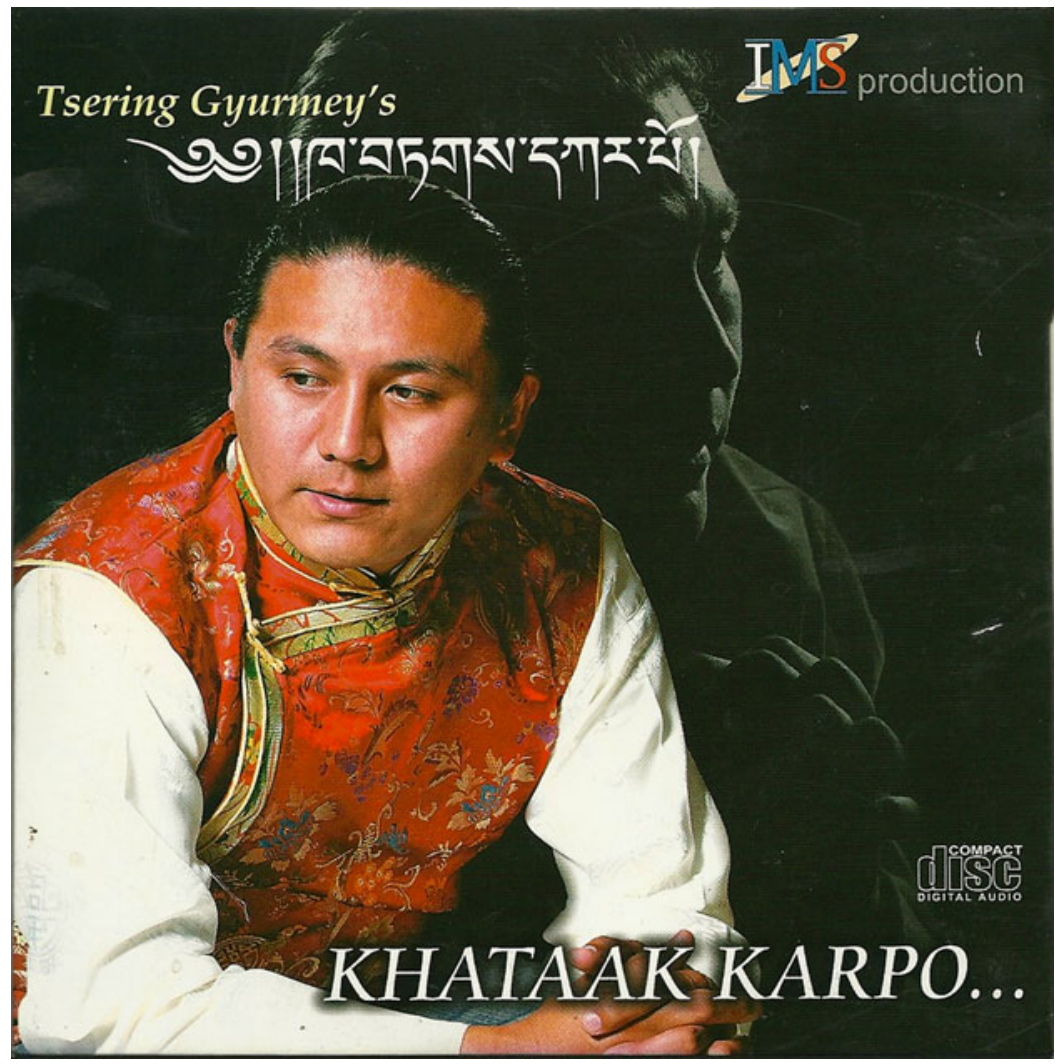

Figure 1. Tsering Gyurme's CD album Khataak Karpo.

songs via computers and, of course, smartphones. As album sales shrunk, music shops closed down, with just two remaining in Kathmandu and only street stalls in Dharamsala and Majnu Ka Tilla. Most distributors (often linked with music shops) also stopped their work. It is now very difficult to recoup the costs of an album. Some singers manage to energetically engage friends in the West to sell their albums, and a handful of singers are also managing to make significant sales in Tibet and recoup the money there, through good contacts. Within India and Nepal, however, there is little scope for sales. Now, the most either of the two shops/distributors in Kathmandu would pay for a master and the right to distribute in Nepal would be around US\$250-300 (Rs 25,000-30,000), where the very lowest costs of making the master for an album are around US\$9,000 (Rs 90,000) (about US $\$ 1,300$ or Rs 130,000 including printing 1,000 copies). A basic, fairly low salary in Nepal is in the region of US\$60 per month (Rs 6,000). The best arena for selling albums is Kalachakra, an important Buddhist tantric teaching initiation lasting several days which attracts vast crowds of over 100,000 people when held by the Dalai Lama. Tibetan music concerts are staged in the evenings. ${ }^{27}$

27 Diehl reports the Yak Band performing for two weeks in a Tibetan settlement in south India in 1995 for evening entertainment during the Kalachakra initiation held there (Diehl 2002, pp. 201-2). 


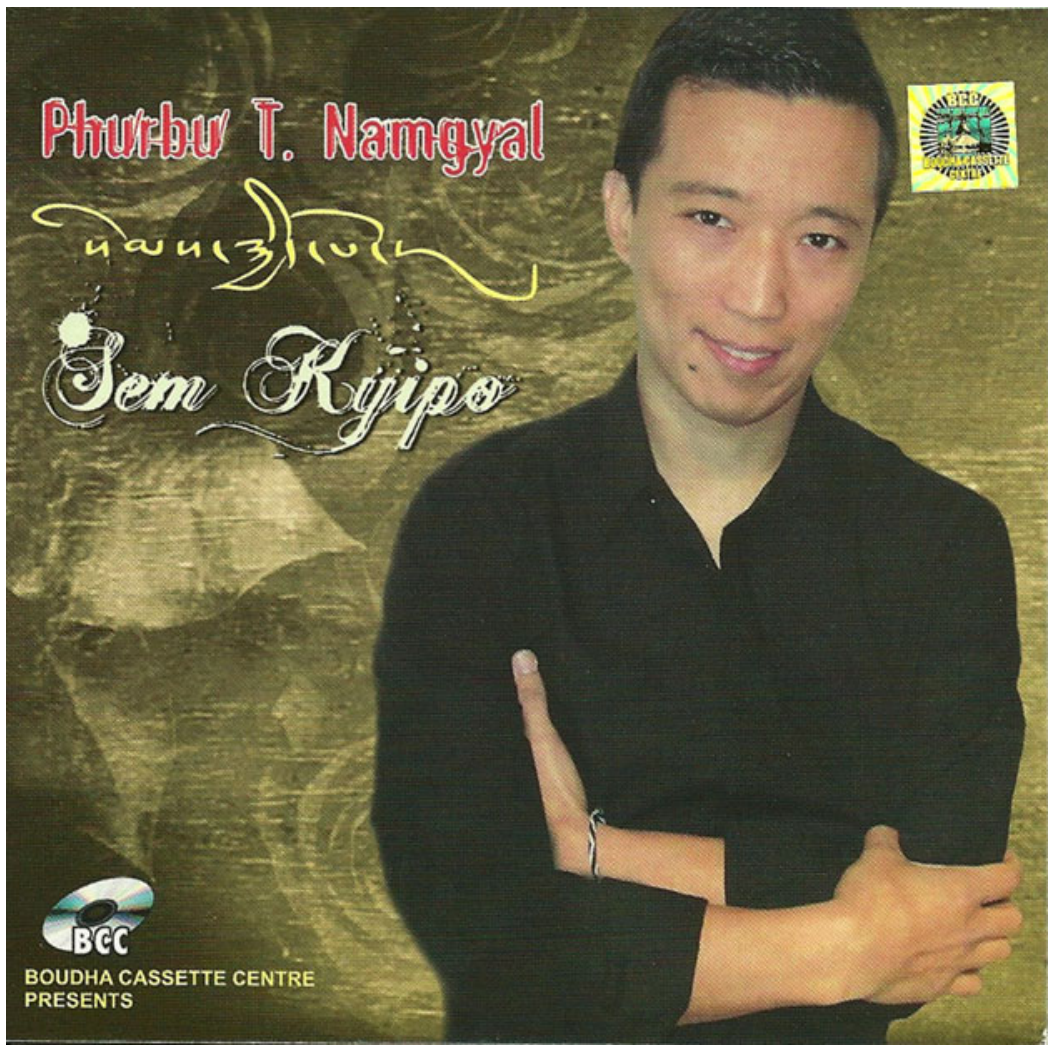

Figure 2. Phurbu T. Namgyal's album Sem Kyipo (2010).

The Internet has also influenced the economics of production by creating a desire or need to make music videos following the widespread dissemination of songs from Tibet in VCD format through YouTube from 2006. Adding a video greatly increases production costs, with the need for much lengthier production (and hence loss of earnings from other work), extensive travel to locations, costs of filming, and more costumes. ${ }^{28}$ I met two new singers in 2013, one a new arrival in Tibet living in Kathmandu, and one based in the USA, who were spending about US\$5,000 and US\$7,000, respectively (Rs 500,000 and 700,000) to make their albums. The singer in Kathmandu had support from friends, not having that kind of money himself, and the one in the USA had borrowed the money, herself living from the income of a basic shift-based job in New York. She was aware that she would not get the money back, but still wanted to make a quality album. The high costs and lack of revenue have led to established singers increasingly abandoning albums, and just looking to make a few songs with videos to release on YouTube - the same approach as in much of the world now. During this time, TIPA have also been producing annual video CDs of songs and dances, funded as before with money from the Central Tibetan Administration and private donors, although these are largely traditional, and Akama is not currently a major force in Tibetan exile pop music.

${ }^{28}$ This has happened in Tibet itself with the move to VCDs, and affected market access (Morcom 2008). 


\section{Live shows}

During much of the 2000s, not only was it possible to at least break even on album sales, but a basic income could be gained by doing live shows in India and Kathmandu. The Tibetan music scene was given a real boost from 2003 with the emergence of two music events organisations. Lobsang Wangyal Productions, which began in 2000, launched the first Tibetan Music Awards in 2003, the year in which Gonpo Entertainments was launched. Gonpo staged the big Losar (Tibetan New Year) concerts with Tibetan audiences of up to 10,000 each year in the Tibetan settlement of Bylakuppe in south India. This added a real sense of showbiz, hype and glamour to Tibetan music. However, neither of these companies run a profit and, in fact, they subsidise music production work from other income, sometimes sustaining losses. The Tibetan Music Awards, which gave Oscar-style statues to winners and held a big ceremony in the TIPA auditorium in Dharamsala for the first couple of years, had then to proceed more modestly with just certificates and a far smaller venue. The big Losar concerts also pay artistes little if anything above travel expenses, although they have offered important scope for selling albums.

Tibetan music concerts reached a new level in 2005 with the first big tour of 13 concerts across the USA and Canada, organised by Gonpo Entertainments in conjunction with local Tibet-related organisations in the USA. Another tour was organised in 2006. A range of other concerts also began to be organised in countries with many Tibetans, especially the USA, Canada, Switzerland, and also Belgium. Concerts in the West, of course, pay considerably better than those in India or Nepal. In the USA, fees in 2013 could be up to around US\$1,000 for the few top singers but were not necessarily always as much as that, and something like US\$300 or US $\$ 400$ for less well-known singers. This is a lot of money for a singer from India or Nepal, but such shows are not frequent and so cannot support a living, since it is expensive to bring singers over from India or Nepal to the USA or Europe. For singers based in India and Nepal, an additional problem is getting a visa, and quite a number of singers are thereby unable to travel. For singers in the USA or Europe, being invited to and attending these concerts is far easier (apart from singers who do not have passports), but they are not regular, ranging from a few per year to, at best, two or three in a given month, as ther are now many singers. Thus concert fees are certainly not enough to live off for singers in the West.

The live Tibetan music scene in Nepal has suffered major blows since 2008 when unrest broke out in Tibet. In Kathmandu, the Chinese authorities have put pressure on the Nepali government to suppress gatherings of Tibetans for fear of protests, and large concerts in Kathmandu have been impossible, although in July 2014 a big celebration of the Dalai Lama's birthday with 4,000 people was able to take place, and this policy may be changing. However, since 2008, singers in Kathmandu have had extremely limited opportunity to gain remuneration for live performance - just sporadic invitations to sing at weddings or private parties.

The 2008 protests in Tibet were suppressed, but from 2011 a wave of selfimmolations spread across Tibet - a total of 135 so far (136 including a somewhat isolated case in 2009), and six in India and Nepal. These self-immolations, many of them filmed with footage circulating on YouTube, have generated immense levels of collective pain and anger for Tibetans inside and outside Tibet. As a result of the protests and the self-immolations, from 2008 to 2013 the Tibetan exile Prime Minister, Lobsang Sangay, announced that Tibetan New Year should not be celebrated. The 
first year the festival was again marked in exile was 2014, reflecting the significant slowdown in self-immolations from 2013-2014. The big Losar concerts were cancelled from 2008-2013, further affecting the livelihoods of Tibetan singers.

\section{Livelihoods}

Although a few singers in India and Kathmandu were able to make a basic living in the 2000s, most kept their day jobs. Since 2008, however, it is only a couple of Tibetan singers who are able to survive through music alone, although several manage to break even or make small profits on albums, enough to help fund the production of new music. There is a real pop scene in exile Tibet, with big concerts, some excellent performers, awards and, at least on stage, a real pop glamour. However, there is not a livelihood behind it. It is only a small handful of exile Tibetan pop singers who survive (very modestly) off music alone, and do not have other regular income. This is an important difference between the Tibetan exile music scene and that in Tibet and in much of the world where, since the collapse of profitability of album sales, musicians have successfully adapted by relying on live performances. A number of the top Tibetan pop singers in Tibet itself have opened up their own nightclubs and have fairly impressive lifestyles and, needless to say, the top English language pop stars like Madonna or Rihanna are firmly in the stratosphere of global wealth.

Tsering Gyurme is the most famous Tibetan pop singer, and one of the few who survives from music alone. He gave up his job as a primary school music teacher in December 1999. However, rather than this being due to his having made a lot of money, it was in fact because he was travelling too much for concerts to continue teaching. Pop music has not made him wealthy. He does not have a car or even a motorcycle, and does not own an iPhone. He is to be seen in Boudha, the main Tibetan area of Kathmandu, Nepal, in fairly normal cafes and restaurants or with friends who own small shops, dressed like other Tibetans, and certainly does not have a glamorous and lavish lifestyle. He says that he has a comparable amount of money to when he was a schoolteacher, with presumably greater income but many more expenses for making new albums. It is important to note that he does not survive by singing alone, but is able to make a living from what he describes as 'music-related' work. The mainstay of this is studio work (playing all the vertical fiddle or piwang music for Tibetan pop music produced in Kathmandu and much of the lute or dranyen too), and also teaching school children Tibetan music privately over the winter months. He also gives some shows abroad, sometimes going on longer tours around the remote ethnically Tibetan areas of Nepal. Through these he can earn enough to live off, over and above expenses, for a matter of weeks or a month, and he enjoys all these activities in terms of the musical and cultural experience they bring. He also said that he was able to subsidise trips he makes to India to sing in concerts there by taking a few dranyen to sell. Needless to say, all of this, in addition to making new albums of his own every year or two, means he is immensely busy.

Given the costs of living in the West, it is inconceivable for pop singers based there to live from music alone. The successful singer Lobsang Tseten was able to make three albums from 2003 to 2006 while living and studying in India, and then settled in Canada in 2006. He has funded two albums since then (only distributed in the West) through working 10 hours a day, six days a week, and recording in 
Kathmandu during vacations. Costs were only partially covered by selling albums at shows in the West. Phurbu T. Namgyal, based in Minneapolis, is one of exile Tibet's most popular pop musicians, comparable to Tsering Gyurme. He has a day job (working in IT), and has no illusions as to any possibility of making music a sole source of income. He is unusual in that since settling in the USA he does not produce his albums from Kathmandu, but creates them online via studios in Bulgaria. He composes all his own songs, most of the lyrics, and does much of the programming. The costs per song (around US\$100) are the same, but he saves the time and money it would take to go to Kathmandu to record. Virtually all his free time is taken up with music, and his prolific output of 11 albums since 1995, including the latest digital release, is the result of immense energy and drivenness. He has a good standard of living in Minneapolis, but this is not related to his status as one of the most successful pop singers of exile Tibet, but due to the fact that he has a regular job, and Tibetans in Minneapolis who are employed on the whole live well.

\section{The economic dynamics of Tibetan pop music}

Gaining critical mass from the mid- to late 1990s, Tibetan exile pop music is very much connected to (global) capitalism. Pop musics in Tibet itself and in exile are both a result, broadly speaking, of the intertwined processes of market liberalisation, technological development and the increased movement and connectivity of people across the globe that have transformed China, India and Nepal in the neoliberal era. These processes have been shaped, of course, by the Chinese occupation of Tibet, the creation of exile Tibet, and the state and quasi-state institutions that have emerged. ${ }^{29}$ For example, albums are made largely in Kathmandu but by Tibetans from across the world, some of whom no longer even go there to record, but manage everything remotely with an arranger based in Kathmandu. There are also growing links between Tibet and exile in terms of creativity and the production of popular music; for example, lyrics, melodies or even arrangements are sent over the Internet between Tibetans inside and outside Tibet, while Tibetan exile singers are constantly connected to smartphones, involved in these communications. The growing amounts of disposable income available to exile Tibetans, including those settled in the West, has also contributed to the ability to fund music production. It has also facilitated musical consumption, with the purchase of music and music video playback, computers and mobile phones, and cassettes, CDs and DVDs.

In fact, exile pop music is indelibly linked to an upper layer of global capitalist commodity production in terms of its use of studio equipment, blank CDs (formerly blank cassettes), printing, design software, etc. and of course computers and the Internet, without which it would not be pop music at all. This is also the case with pirate copies of Tibetan albums. At an even more fundamental level, the basic necessities of life such as food, clothing, housing, medicine and so on that Tibetan exiles depend on are to a large degree linked into immense verticalities of accumulation and global capitalism and, of course, regulated by nation states. These commodity chains are also a bedrock on which traditional Tibetan music is preserved in exile.

29 Due to civil war and other political problems, the changes in Nepal have been less dramatic; but from the early 1990s, Kathmandu was developed and highly cosmopolitan due both to the tourist industry and also a concentration of diplomatic and aid-related foreign personnel. 
Thus there is no 'outside' of capitalism in exile Tibetan life (or, indeed, in virtually any life on the globe now).

Tibetan exile pop music has become a thriving scene with large numbers of singers who have released albums. Despite catering to a tiny population of 130,000 , this pop music is a cultural, stylistic and aesthetic force that can certainly hold its head up next to the music being created in Tibet itself, where there are around 6 million Tibetans. Indeed, it is very popular there (although not legally distributed), despite its far cheaper budgets and lower production standards, and a number of singers have made cover albums of songs produced in exile, particularly those by Phurbu T. Namgyal. Thus Tibetan exiles do not have to rely just on Hindi or Nepali music or English language music, as they did before, or music from Tibet, which is extremely popular particularly among Tibetans who have come from Tibet. $^{30}$ Thus exile Tibetan pop music, although curtailed in Tibet by the authorities, is still an extremely important and vibrant form of communication and shared culture with Tibetans in Tibet. However, it is not possible to describe this music as 'commercial' or capitalist because it is not a vehicle of capital accumulation or made with a profit motive.

The question, then, arises as to what Tibetan pop music is, in its social economy. Singers sing because they love music, and also because they see its political potential. Within Tibetan exile society more generally, however, singing is not seen as something that should be rewarded with large amounts of money and is not given particularly high respect, although people love to hear songs and appreciate talented singers, and some large music concerts take place. Status is more typically and reliably gained through education (modern or monastic), and also through being successful in business, and performers, including pop musicians, are generally not highly educated or rich (this is of course something of a vicious circle). The low status of musicians also links to pre-modern Tibet, where professional musicians were framed with the dynamics of patronage where music was a service paid for by people of high status and performed by those of low(er) status. ${ }^{31}$ Although these attitudes are changing, ${ }^{22}$ there is still a sense that singers should not be paid highly. Several singers stated that this lack of valuing of singers is because music is typically seen as 'community work' (using that phrase in English). This links with the amateur nature of much singing in pre-modern Tibet and, indeed, the still vigorous practice of live, ad hoc singing at parties. People singing pop music at community functions is in many ways an extension of this. Similarly, singing is also a vibrant form of communication on audiovisual-based social media messaging services, with exile Tibetan singers frequently song-messaging other singers, friends and family (including in Tibet) with songs and videos taken from their albums, or raw singing.

However, the sense of 'community work' also links to the distinctly modern predicament of exile Tibet of being in exile, and trying to preserve culture and identity. Exile Tibet was founded on emergency practical and financial charitable help as

30 Those born in exile often see this music as having too much Chinese influence, and a lot of it is from regions of Tibet such as Amdo that have dialects they do not understand. See Morcom (2004, Chapter 6) for an albeit slightly out-of-date discussion of the problems of Tibetan identity in music from Tibet and exile.

31 See Qureshi's (2002) paradigmatic analysis of feudal patronage of north Indian art music.

32 The current situation of the 2010s appears better than that described by Diehl from the 1990s (Diehl 2002, pp. 192-200). 
tens of thousands of refugees fled Tibet, and still gains extensive support from sponsorship, both from outsiders and Tibetans themselves. ${ }^{33}$ Music, as a part of 'Tibetan culture', is something that must be preserved, and is a collective duty of all Tibetans, with the 'paradigm of preservation' a defining ideology of exile Tibet (Diehl 2002). ${ }^{34}$ Most of the big music shows across the USA and also Europe are in fact done for charitable fundraising for Tibetan causes and institutions (Figure 3). Thus there is an expectation for singers to be singing primarily for the community rather than individual gain. A great many Tibetan performers sing and dance for free and some specifically say they do not want to take money for performing. This is more common among performers of traditional music, who teach for free at the weekends in community centres. Pop singers are invariably very keen to support the wider cause of Tibet and cultural preservation, and one or two singers explicitly stated their responsibility as 'messengers' of the community. However, given the expense of producing pop music, singers are also keen to earn enough money to at least cover these costs, ideally to be able to produce better and/or more music, although there is little hope or even a real desire to be able to earn the quantities that would support a livelihood solely from music in the West, or to grow rich from music. Tibetan exile singers have worked hard to negotiate payment in big Tibetan concerts in Western countries in particular (even fundraising concerts) since around the mid-2000s. However, if a pop singer from Nepal is invited, they are paid considerably more than even the top Tibetan singers, in the region of US $\$ 3,000$ as opposed to US $\$ 1,000$. This demonstrates the notion that Tibetan culture (especially music) is seen as something people should not be making money from but doing anyway as community work.

In these ways, Tibetan exile pop music, although monetised and massproduced by electronic media, can be seen as being embedded (to use Polanyi's terminology) in Tibetan exile society, functioning largely in terms of subsistence social (re)production in the manner of much pre-modern folk music or, to use Braudel's model of the capitalist system, as lying in the lower or to some extent middle layers. Tibetan exile pop music is limited in its capitalisation by the small-scale market and piracy, but also by social attitudes that see individual accumulation from (community) music as unacceptable. However, we cannot see Tibetan exile music as disconnected from capitalism, such as the pre-modern cultures explored in economic anthropology where wealth and surpluses were given away or destroyed in events described paradigmatically as potlatches (Mauss 1954[1925]; Polanyi 2001[1944], pp. 45-58). In exile society, accumulation from culture is not easily accepted, but accumulation is not wrong per se, since it is seen as a great achievement to get rich through business. There are singers who have become (presumably) significantly wealthy through success in the world music scene - for example, Yungchen Lhamo and Nawang Khechog, and also Ani Choying Dolma. ${ }^{35}$ However, they are to a large extent distanced from the lives and community events of ordinary exile Tibetans.

33 This money is not outside of world capitalism, deriving from individual or state surpluses (including the voluntary 'taxes' of exile Tibet which, with many Tibetans living in Western countries, are not inconsiderable).

${ }^{34}$ It is to be noted that the Tsering Gyurme gains much respect from being a performer of traditional Tibetan music, which he does alongside his pop music.

35 The case of Ani Choying Dolma is again different since she is a nun, and is not amassing a personal fortune (something that would be unquestionably unacceptable in Tibetan society), but rather gives the proceeds from her music to charitable projects. The economics and logics of the exchange of recorded Buddhist chants targeted at foreign markets are too complex to detail in this paper. 


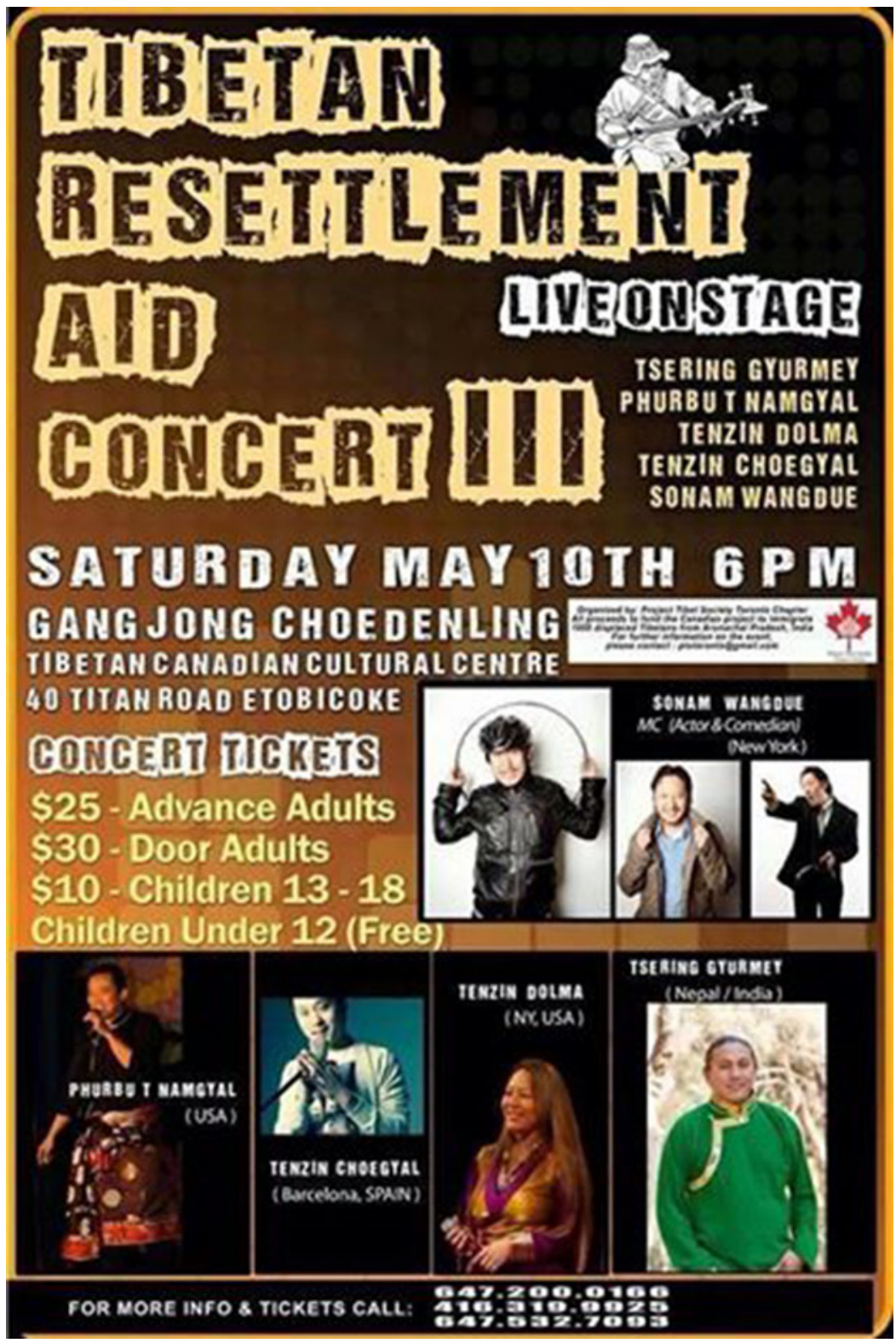

Figure 3. Poster for a fundraising concert in Toronto for the resettlement of Tibetans there from India.

The subsistence nature of exile Tibetan pop music should also be distinguished from music, including pop music, that is supported to a large degree from patronage, money given by high status or wealthy individuals or organisations (or government). In Tibet itself, there is a considerable role of patronage (or subsidy) of popular music by the Chinese state and by wealthy businessmen and members of the religious establishment (Morcom 2008; Gayley 2011, forthcoming). In exile, patronage as such has not played a significant role in music, beyond support of TIPA, with major surplus resources typically going into such things as religion, education or 
health. ${ }^{36}$ Money that funds music in exile Tibet is more generally given to singers by family members or friends, sometimes in the form of loans to be paid back later. Often, singers simply save up to fund their music.

I would also make a sharp distinction between the non-money making nature of Tibetan exile pop music and logics of cultural and social capital (Bourdieu 1984). In Bourdieu's model, individuals pursue activities to accrue social and cultural capital for rational, individual gain which, as Graeber has elaborated, is squarely grounded in a capitalist rationality of value creation (Graeber 2001, pp. 27-8). This theory has been effectively applied, for example, to Western classical music (in the Western world and east Asia) where parents clearly do pay for their children to study music for reasons of class status (Kraus 1989; Small 1998). However, this is difficult to reconcile with the fairly low status of being a musician in Tibetan exile society. Bourdieu's concepts of social and cultural capital also work within a context of class in capitalist societies. For this reason, too, this theory is problematic in a context like Tibetan exile society where there is no significant conflation of social/cultural stratification in Tibetan music. The model is more useful in Tibet itself, where capitalist class formation and cultural stratification have been clearly developing in the wake of the dramatic post-2000 economic development of Tibet (Morcom 2007).

A body of work has emerged looking at the post-object non-profit economy of much English language popular music in terms of gift exchange, deriving from the work of Mauss (1954[1925]). Rather than trying to sell recordings, musicians give them away for free and this impels fans to reciprocate this gift, coming to gigs or buying merchandise. This exchange builds inalienable social bonds between singers and fans (Baym 2011; Anderson 2014). Successful artistes are able to gain a livelihood from music in this way, although the quantities of time spent in building fan relationships via online social media can be difficult to distinguish from a day job (Anderson 2014). This logic of gift exchange can serve as a means to break into big scenes, and thus can be connected to capitalist exchange, profit and accumulation. ${ }^{37}$

Musical gift economies, facilitated by digital media, however, also involve scenes where people do not expect or even want to make money from music, for example Swedish independent pop music, written about by Baym (2011), where there is a conscious resistance to big corporate music. In the Tibetan case there is no sense of resistance or even attention given to 'the music industry', as exile Tibetan popular music is discontinuous with any big scene. There is, moreover, no conscious discourse of music as something to be given (for free), which listeners and audiences will in some way respond reciprocally to. However, music in exile Tibetan society can be seen as a kind of a gift-type 'exchange media' (Stokes 2002, p. 147) that weaves relationships and social fabric in inalienable ways, rather than

${ }^{36}$ However, for the Kalachakra teaching by the Dalai Lama of July 2014, held in Ladakh, music performers involving unprecedentedly large numbers of Tibetan performers from across the world were funded by the Tibetan businessman Tenzin Dhondup via his HITA (Himalayan International Traditional Arts) Music Agency. However, the intention, even with flying perhaps as many as 50 Tibetan singers to Ladakh from various locations, was to break even, given the vast crowds at Kalachakra. However, it is very unlikely that this happened.

37 It is possible to see the reciprocal logic of gift exchange (and also patronage) segue into notions of status and thus social capital and more capitalistic contexts of exchange. Indeed, Bourdieu saw gift exchange as equivalent to social/cultural capital, with the former simply involving a longer delay in payback (Graeber 2001, pp. 27-8). While this is debatable, there are certainly ways in which the one could become the other, depending on context. 
existing as a (theoretically) entirely alienable capitalist commodity (Graeber 2001, pp. 36-7, 45). However, as stated, these forms of exchange exist within global capitalism, illustrating clearly its 'patchwork-like' nature.

\section{Conclusions}

As I have explored in this paper, rather than looking at whether a given musical style or scene is or is not 'capitalist', locating music in capitalism necessitates looking at ways in which musical cultures connect (unevenly and with inevitable elisions) to capitalism as a world system: its lowest subsistence layer, the middle layer of market exchange, and the capitalist layer of the anti-market at the top. Tibetan exile pop music is not a direct medium of capital accumulation. It nestles within the world system, but is maintained as something of an air pocket, distinct to some degree from the upper layer. It exists within and because of the whole system, including the upper layer and the vast chains of commodities and accumulation, but it has certain kinds of separateness. Or, to employ other metaphors: it can be said to be among infinite and shifting spots of turbulence within a greater atmosphere of smooth(er) flows of capital; what Holloway has described as a crack (that may be filled and closed or expanded); or a (small) sinkhole. However, it does not disrupt the world system as a whole, and this and other arenas that are in and of themselves noncapitalist are not necessarily a sign of resistance to capitalism, are not outside it, let alone a sign of its breakdown. Rather, they lie within its lower and middle layers. Tibetan exile pop music is a potential form of capital accumulation and, if piracy ended and the culture of music as 'community work' was eroded, singers could make more money, and Tibetan exile pop music could connect directly to chains of capital accumulation and the anti-market through big music companies. The value, money and status of pop music and musicians in exile Tibet could then segue into new configurations of cultural or social capital and accumulation and this small crack could close. However, at the moment, it is an example of capitalism's inherent unevenness or porosity, its essentially layered nature, shaped by technology, the scale of markets and by cultural norms and priorities.

The intensification of capital's control on music described by Azenha (2006), Carah (2010), Taylor (2012) and Eckhardt and Bradshaw (2014) would seem to be a different world from subsistence forms like exile Tibetan pop music, patronagebased small scenes or digital gift economies. However, looking at capitalism as a world system, as I have discussed, exile pop music has emerged firmly within the context of global capitalism and the hegemonic forces are clear, including in relation to musical style. The apparent contradiction between the intensification of capitalism's control on music and its breakdown can be connected more specifically using recent work on markets and technology. Chris Anderson's (2006) idea of 'long tail' economics explains how digital technologies have enabled the proliferation of many more small businesses, which would have failed in previous models. ${ }^{38} \mathrm{~A}$ less utopian model is that of 'winner-takes-all' markets described by Robert Frank and Philip Cook (2010[1995]). They state, regarding cultural production, 'To be sure, it is easier than ever to purchase an obscure book or rent a little-known film. But that doesn't mean that producing obscure books and films has become

${ }^{38}$ See (Tim) Anderson (2014) for a discussion of this in the context of digital music economies. 
economically attractive' (Frank and Cook 2010[1995], pp. loc 186). Thus phenomena such as exile Tibetan pop music can be seen as part of the larger system, but as lying within the vast arena of the non-winners. It remains small scale, non-accumulating and, in and of itself, not capitalist. However, the situation is complex because Tibetan exile pop music is not linked to any big scene; it is only Tibetan 'new age' or 'world music' singers such as Yungchen Lhamo or Nawang Khechog, who draw on traditional music rather than a synthy pop format, who can access a big scene. With digital technology enabling micro-scale (albeit unprofitable) production bounded by ethnic groups, more and more pop (and other) music across the world may be seen as connected to capitalism in the form of air pockets nestling in, relying on and shaped by the whole system including the upper layer, rather than long-tail or winner-takes-all markets that directly feed into these verticalities of accumulation. Thus, with technological and other change, and with now virtually no part of the globe not yet reached by capitalism, Braudel's layers can be seen to operate in a number of ways.

Looking at the growth of capitalism as an ontologically uneven and layered, yet powerfully hegemonic world system opens up new ways of seeing the economic history of music and capitalism as something non-linear and inconsistent. The capitalist nature of a given form of music or music making is not simply a factor of monetisation or marketisation or technological or stylistic format and it cannot be judged in isolation. Pop music was born of capitalism and certain forms of technology in the USA. However, that people create 'pop' music in terms of performance or musical style, and in terms of the machinery and technology of its production, does not mean that it is necessarily 'commodified', a commodity, and 'capitalist' in its political economy. Just because pop music was born of Fordist capitalism and recording technologies does not mean it must always be 'capitalist' and a commodity any more than the fact that Western or Indian classical music was born of feudal patronage systems means that they will always be feudal. In fact, Western classical music is at present more 'capitalist' than exile Tibetan pop music in terms of flows of accumulation and also in terms of the accumulation of social and cultural capital. The Buddhist chanting music produced in exile Tibet is also more 'capitalist' than the pop music, although there are some strong taboos against individual accumulation from this music, making its case complex.

Connecting given cultures of music making with global processes of capital accumulation in this way can also enable us to bring the state firmly into the history and remit of music and capitalism, with scholars such as Marx, Polanyi, Wallerstein and Arrighi having placed the state as core to the growth of capitalism. State subsidies, gained through the taxation of capitalist commerce, or processes of accumulation by the state itself, are a fundamental force in the growth of Western classical music from Renaissance Italy onwards (with city states as opposed to modern nation states in operation) and, as global trade and colonialism developed, many forms of music across the world. Thus, rather than focusing on particular musical formations and the extent to which they are 'capitalist', it is possible to explore a range of different connections to hegemonic capitalism, and uncover dynamic and often subtle processes of power and change in musical styles and cultures. 


\section{References}

Adorno, T. 1978[1938]. 'On the fetish-character in music and the regression of listening', In The Essential Frankfurt School Reader, ed. A. Arato and E. Gebhardt (Oxford, Oxford University Press), pp. 270-99

Anderson, C. 2006. The Long Tail: Why the Future of Business Is Selling Less of More (London, Random House Business Books)

Anderson, T.J. 2014. Popular Music in a Digital Music Economy: Problems and Practices for an Emerging Service Industry (New York and London, Routledge)

Arrighi, G. 2009[1994]. The Long Twentieth Century: Money, Power and the Origin of Our Times (London and New York, Verso)

Azenha, G.S. 2006. 'The internet and the decentralisation of the popular music industry: critical reflections on technology, concentration and diversification', Radical Musicology, 1

Baranovitch, N. 2003. China's New Voices: Popular Music, Ethnicity, Gender and Politics (Berkeley, CA and London, University of California Press)

Barber, B. 1995. 'All economies are "embedded": the career of a concept, and beyond,' Social Research, 62/2, pp. 387-413

Baym, N. 2011. 'The Swedish model: balancing markets and gifts in the music industry', Popular Communication, 9/1, pp. 22-38

Bourdieu, P. 1984. Distinction: A Social Critique of the Judgement of Taste (London, Routledge)

Braudel, F. 1982. The Wheels of Commerce (New York, Harper and Row)

Butterworth, J. 2014. 'The ethics of success: paradoxes of the suffering neoliberal self in the Andean Peruvian music industry', Culture, Theory, and Critique, special issue 'Music, Music-Making and Neoliberalism', ed. J. F. León

Carah, N. 2010. Pop Brands: Branding, Popular Music, and Young People (New York, Peter Lang Publishing)

Diehl, K. 2002. Echoes from Dharamsala: Music in the Life of a Tibetan Refugee Community (Berkeley, CA, University of California Press)

Eckhardt, G.M., and Bradshaw, A. 2014. 'The erasure of antagonisms between popular music and advertising', Marketing Theory, 14/2, pp. 167-83

Frank, R.H., and Cook, P.J. 2010[1995]. The Winner-Take-All Society: Why the Few at the Top Get So Much More Than the Rest of Us (London, Virgin Books)

Fraser, N. 2012. 'Can society be commodities all the way down? Polanyian reflections on capitalist crisis', Working Paper No. 18, Foundation Maison Des Sciences De L'Homme

Frith, S. and Marshall, L. (eds) 2004. Music and copyright (second edition), Edinburgh: Edinburgh University Press

Gayley, H. 2011. 'The ethics of cultural survival: a Buddhist vision of progress in Mkhan Po 'Jigs Phun's heart advice to Tibetans for the 21st century', in Proceedings of the Eleventh Seminar of the International Association of Tibetan Studies, 2006, Königswinter

Gayley, H. Forthcoming. "T-Pop and the Lama: Buddhist "rites out of place" in Tibetan monastery-produced VCDs', In Religion and Modernity in the Himalaya, ed. M. Sijapati and J. Birkenholtz (New York and London, Routledge)

Graeber, D. 2001. Toward an Anthropological Theory of Value: The False Coin of Our Own Dreams (New York, Palgrave)

Harvey, D. 2006. Spaces of Global Capitalism: Towards a Theory of Uneven Geographical Development (New York and London, Verso)

Harvey, D. 2006[1982]. Limits to Capital (London and New York, Verso)

Harvey, D. 2014. Seventeen Contradictions and the End of Capitalism (London, Profile Books)

Hellier-Tinoco, R. 2011. Embodying Mexico: Tourism, Nationalism and Performance (New York, Oxford University Press)

Henrion-Dourcy, I. 2005. 'Women in the performing arts: portraits of six contemporary singers', In Women in Tibet, Past and Present, ed. J. Gyatso and H. Havnevik (London, C. Hurst) pp. 195-258

Holloway, J. 2010. Crack Capitalism (London and New York, Pluto Press)

Hughes-Freeland, F. 2012. 'Movement on the move: performance and dance tourism in southeast Asia', In Dancing Cultures: Globalization, Tourism and Identity in the Anthropology of Dance, ed. H.N. Kringelbachand and J. Skinner (New York and Oxford, Berghahn Books), pp. 100-20

Kraus, R. 1989. Pianos and Politics in China: Middle-Class Ambitions and the Struggle Over Western Music (Oxford, Oxford University Press)

Krims, A. 2001. 'Marxism, urban geography and classical recording: an alternative to cultural studies', Music Analysis, 20/3, pp. 347-63

Laing, D. 2003. 'Music and the market: the economics of music in the modern world', In The Cultural Study of Music: A Critical Introduction, ed. M. Clayton, T. Herbert and R. Middleton (London and New York, Routledge)

Manuel, P. 1993. Cassette culture: Popular music and technology in North India. Chicago: University of Chicago Press

Marx, K. 1990[1867]. Capital: A Critique of Political Economy, Vol. I (London, Penguin Books) 
Mauss, M. 1954[1925]. The Gift: Forms and Functions of Exchange in Archaic Societies (Mansfield Centre, CT, Martino Publishing)

McConnell, F. 2009. 'De facto, displaced, tacit: the sovereign articulations of the Tibetan government-in-exile', Political Geography, 28, pp. 343-52

Morcom, A. 2004. Unity and Discord: Music and Politics in Contemporary Tibet (London, Tibet Information Network)

Morcom, A. 2007. 'Modernity, power and the reconstruction of dance in post 1950s Tibet', Journal of the International Association of Tibetan Studies, 3

Morcom, A. 2008. 'Getting heard in Tibet: music, media and markets', Consumption, Markets and Culture, 11/4, pp. 259-85

Morcom, A. 2011. 'History, traditions, identities and nationalism: drawing and redrawing the musical cultural map of Tibet', in Proceedings of the Eleventh Seminar of the International Association of Tibetan Studies, 2006, Königswinter

Morcom, A. 2013. Illicit worlds of Indian dance: Cultures of exclusion. London: C. Hurst \& Co.; New York: Oxford University Press.

Morcom, A. 2015. 'Terrains of Bollywood dance: neoliberalism and the transformation of cultural economies', Ethnomusicology, 59/2, pp. 288-314

Neveling, P. 2013. 'Capitalism: the most recent 71 years (for example/includes references to refrigerators)', paper given at the Annual Meeting of the American Anthropological Association, 22 November, Chicago, IL. https://www.academia.edu/5259391/Capitalism_The_most_recent_71_years_for_example_includes_references_ to_refrigerators (accessed 26 July 2014)

Neveling, P. 2014. 'Structural contingencies and untimely coincidences in the making of neoliberal India - the Kandla Foreign Trade Zone, 1965-1991', Contributions to Indian Sociology, 48/1, pp. 17-43

Paoletta, M. 2005. 'Making the brand: turning bands into brands', Billboard, 20 September, p. 20

Pegg, C., et al. 2001. 'Tibetan music', In Grove Music Online (Oxford, Oxford University Press)

Polanyi, K. 1957. 'The economy as instituted process', In Trade and Market in the Early Empires: Economies in History and Theory, ed. K. Polanyi, C.M. Arensberg and H.W. Pearson (New York and London, The Free Press and Collier-Macmillan), pp. 243-70

Polanyi, K. 2001[1944]. The Great Transformation: The Political and Economic Origins of Our Time (Boston, MA, Beacon Press)

Polanyi, K., Arensberg, C.M., and Pearson, H.W. (ed.) 1957. Trade and Market in the Early Empires: Economies in History and Theory. (New York and London, The Free Press and Collier-Macmillan)

Qureshi, R.B. 2002. 'Mode of production and musical production: is Hindustani music feudal?', In Music and Marx: Ideas, Practice, Politics, ed. R.B. Qureshi (New York and London, Routledge), pp. 81-105

Rees, H. 2003. 'The age of consent: traditional music, intellectual property and changing attitudes in the People's Republic of China', British Journal of Ethnomusicology, 12/1, pp. 137-71

Scarangella-McNenly, L. 2012. 'Performance in tourism: transforming the gaze and the tourist encounter at Hiwus Feasthouse', In Dancing Cultures: Globalization, Tourism and Identity in the Anthropology of Dance, ed. H.N. Kringelbach and J. Skinner (New York and Oxford, Berghahn Books), pp. 77-99

Schumpeter, J.A. 1975[1942]. Capitalism, Socialism and Democracy (New York, Harper)

Small, C. 1998. Musicking: The Meanings of Performing and Listening (Middletown, CT, Wesleyan University Press)

Stokes, M. 2002. 'Marx, money, and musicians', In Music and Marx: Ideas, Practice, Politics, ed. R.B. Qureshi (New York and London, Routledge), pp. 139-66

Taylor, T. 2007. 'The commodification of music at the dawn of the era of "mechanical music"', Ethnomusicology, 51/2, pp. 281-305

Taylor, T. 2012. The Sounds of Capitalism: Advertising, Music and the Conquest of Culture (Chicago, IL and London, University of Chicago Press)

Wallerstein, I. 2014[1983]. Historical Capitalism: With Capitalist Civilization (London and New York, Verso)

Whittaker, L. 2014. 'Refining the nation's "new gold": music, youth development and neoliberalism in South Africa', Culture, Theory and Critique, special issue 'Music, Music-Making and Neoliberalism', ed. J.F. León

Zla ba Sgrol ma. 2012. 'Silence in the valley of songs: work songs from Sman shod valley', Asian Highlands Perspectives, 12 